\title{
Antimicrobial and Immunomodulatory Effects of Bifidobacterium Strains: A Review
}

\author{
Hyun Jung Lim and Hea Soon Shin* \\ College of Pharmacy, Duksung Women's University, Seoul 01369, Republic of Korea
}

\begin{abstract}
Bifidobacterium strains can provide several health benefits, such as antimicrobial and immunomodulatory effects. Some strains inhibit growth or cell adhesion of pathogenic bacteria, including multidrug-resistant bacteria, and their antibacterial activity can be intensified when combined with certain antibiotics. In addition, some strains of bifidobacteria reduce viral infectivity, leading to less epithelial damage of intestinal tissue, lowering the virus shedding titer, and controlling the release of antiviral substances. Furthermore, bifidobacteria can modulate the immune system by increasing immunoglobulins, and inducing or reducing pro- or antiinflammatory cytokines, respectively. In particular, these anti-inflammatory effects are helpful in the treatment of patients who are already suffering from infection or inflammatory diseases. This review summarizes the antimicrobial effects and mechanisms, and immunomodulatory effects of Bifidobacterium strains, suggesting the potential of bifidobacteria as an alternative or complementary treatment option.
\end{abstract}

Keywords: Antimicrobial, antiviral, bifidobacteria, probiotics

\section{Introduction}

Bifidobacteria are gram-positive, strict anaerobic, pleomorphic rods. The name 'Bifidobacterium' signifies the branching morphology of the bacteria-'bifidus' in Latin means cleft in two parts. In addition to their main phenotypic characteristic of producing lactic acid, bifidobacteria produce acetic acid that suppresses the growth of harmful bacteria due to its strong bactericidal action $[1,2]$.

Bifidobacterium was first isolated in 1899 from the feces of healthy breast-fed infants by Tissier of the Pasteur Institute in France. At birth, many bacterial species gain access into the intestinal tract of infants; however, bifidobacteria gradually become established as the main bacteria, and predominate in the intestinal microflora during the neonatal period, especially in breast-fed infants. As the intestinal microflora changes with age, there is an accompanying reduction in the percentage of bifidobacteria $[3,4]$.

Amongst approximately 1000 species of bacteria in the gut, harmful bacteria are those which possess pathogenicity or transform food components into harmful substances [5]. A favorable intestinal microflora consists of a low level of harmful bacteria and a high level of beneficial bacteria, the latter represented by bifidobacteria. In the large intestine, the number of Lactobacillus is approximately $1 \%$ that of Bifidobacterium [6].

Bifidobacteria help in maintaining the intestinal microbial balance owing to their potentially beneficial physiological effects. Bifidobacteria are ingested as probiotics to improve the intestinal microflora balance. This, in turn, improves the intestinal environment and contributes to the overall health of the intestine, with the ultimate aim to prevent or treat intestinal tract diseases or infection. In addition, studies have shown that bifidobacteria enhance several immune response processes, including promoting the involvement of macrophages and lymphocytes.

Here, we provide a broad review of several Bifidobacterium strains as the most promising probiotic species, and discuss their antibacterial, antiviral, anti-inflammatory, and pro-inflammatory effects. This review also examines recent studies on several Bifidobacterium strains that investigated their antimicrobial mechanisms and immunomodulatory effects in certain disease conditions.

\begin{abstract}
Antimicrobial Effects
Antibacterial Effects

Several studies have shown that a number of Bifidobacterium strains have antibacterial activity against various pathogens, including Escherichia coli, Salmonella typhi [7], Streptococcus mutans [8], Propionibacterium acnes [9], and Listeria monocytogenes [10]. Moreover, some studies have reported that Bifidobacterium strains can be used against multidrug-resistant pathogens. One study showed that probiotics, including some Lactobacillus strains, could inhibit or remove the biofilm formed by multidrug-resistant $E$. coli; amongst all the tested probiotics, B. longum showed the strongest inhibition against the biofilm formed by E. coli IC2 [11].
\end{abstract}


Bifidobacterium strains, such as B. adolescentis, B. pseudocatenulatum, and B. longum, were found to inhibit the growth of vancomycin-resistant $S$. aureus and vancomycin-resistant Enterococcus [12]. The cytoprotective effects of bifidobacteria, and their activity against multidrug-resistant $S$. aureus (MRSA), were investigated in mice treated with multiple antibiotics and then infected with MRSA, followed by treatment with 5-fluorouracil. The results showed that the antibacterial effect was more pronounced when $B$. breve and galactooligosaccharides were combined as synbiotics, compared to $B$. breve alone [13]. Another study by Yang et al. showed that the antibacterial activity of $B$. breve against Clostridium difficile was enhanced when combined with certain antibiotics, such as metronidazole, clindamycin, and ceftazidime [14]. Oral administration of B. longum with L. rhamnosus increased the concentration percentage of $B$. longum in the intestine, and the effect lasted for one month after the end of probiotic intake. In addition, the intestinal microflora composition was affected at the phyla and species levels, resulting in a reduction in harmful bacteria, such as Ruminococcus gnavus (which possess different pathogenic traits and virulence factors), and an increase in beneficial bacteria, including Akkermansia muciniphila, which is closely related to human health and inversely associated with body fat mass and glucose intolerance (Table 1) [15].

\section{Antiviral Effects}

Many studies investigating the antiviral effects of bifidobacteria have focused on their activity against rotavirus, one of the most important pathogens that causes diarrhea and dehydration in children, resulting in numerous deaths in developing countries [16]. In an in vitro study, the administration of $B$. thermophilum inhibited rotaviral adherence to Caco-2 and HT-29 cells, and maintained the viral titer at a low level. In another study, pretreatment with $B$. thermophilum led to less epithelial damage of intestinal tissue, followed by its recovery to a normal state [17]. Similar results were observed when porcine intestinal epitheliocytes were pretreated with $B$. infantis or B. breve [18]

The antiviral effects of bifidobacteria were demonstrated in several in vivo studies as well. In mouse models, a lower virus shedding titer and shorter diarrhea period were observed, and these protective effects were more evident in colonized and vaccinated neonatal gnotobiotic pigs than in non-colonized and vaccinated neonatal gnotobiotic pigs [19]. In another study, oral administration of B. infantis led to an approximate $67 \%$ increase in

Table 1. Antibacterial effects of Bifidobacterium spp.

\begin{tabular}{|c|c|c|c|}
\hline Reference & Strain(s) & Outcomes and results & Discussion \\
\hline Inturri et al. [7] & $\begin{array}{l}\text { B. longum, } \\
\text { L. rhamnosus }\end{array}$ & $\begin{array}{l}\text { - Both strains inhibited pathogens } \\
\text { (E. coli, S. enteritidis, and S. typhi), } \\
\text { both alone and in combination } \\
\text { - Inhibited attachment of pathogenic } \\
\text { bacteria to HT-29 cells }\end{array}$ & $\begin{array}{l}\text { Probiotics inhibited gram-negative } \\
\text { pathogens, and the inhibitory effect } \\
\text { was stronger in combination }\end{array}$ \\
\hline Lee et al. [8] & $\begin{array}{l}\text { B. adolescentis, } \\
\text { B. longum }\end{array}$ & $\begin{array}{l}\text { - Proliferation of } \\
\text { S. mutans, S. sobrinus, S. gordoni, and } \\
\text { Aggregatibacter } \\
\text { actinomycetemcomtans decreased } \\
\text { - Live bacteria showed stronger activity }\end{array}$ & $\begin{array}{l}\text { The administration of } B \text {. adolescentis } \\
\text { may be useful in preventing cavities }\end{array}$ \\
\hline Lee et al. [9] & $\begin{array}{l}\text { B. adolescentis, } \\
\text { B. pseudo-catenulatum, } \\
\text { B. longum }\end{array}$ & $\begin{array}{l}\text { - Antibacterial activity against } \\
\text { Propionibacterium acnes, S. aureus, } \\
\text { S. epidermidis, and VISA increased }\end{array}$ & $\begin{array}{l}\text { Bifidobacterium spp. inhibited the } \\
\text { growth of } P \text {. acnes and thus could be } \\
\text { used to treat acne }\end{array}$ \\
\hline $\begin{array}{l}\text { Muñoz-Quezada } \\
\text { et al. [10] }\end{array}$ & $\begin{array}{l}\text { L. paracasei, } \\
\text { L. rhamnosus, } \\
\text { B. breve }\end{array}$ & $\begin{array}{l}\text { - Antibacterial effect against Listeria } \\
\text { monocytogenes increased }\end{array}$ & $\begin{array}{l}\text { Probiotics were useful in preventing } \\
\text { meningitis caused by L. monocytogenes }\end{array}$ \\
\hline $\begin{array}{l}\text { Abdelhamid et al. } \\
\text { [11] }\end{array}$ & $\begin{array}{l}\text { L. acidophilus, } \\
\text { L. rhamnosus, } \\
\text { B. longum, } \\
\text { B. bifidum }\end{array}$ & $\begin{array}{l}\text { - Biofilm formation of E. coli IC2 and } \\
\text { WW1 was inhibited }\end{array}$ & $\begin{array}{l}\text { Probiotics removed the biofilm formed } \\
\text { by multidrug-resistant E. coli }\end{array}$ \\
\hline Yoon et al. [12] & $\begin{array}{l}\text { B. adolescentis, } \\
\text { B. pseudo-catenulatum, } \\
\text { B. longum }\end{array}$ & $\begin{array}{l}\text { - Growth inhibition activity against } \\
\text { VISA and VRE increased }\end{array}$ & $\begin{array}{l}\text { Bifidobacteria were beneficial when } \\
\text { administered in combination with } \\
\text { antibiotics, in diseases caused by } \\
\text { superbacteria }\end{array}$ \\
\hline $\begin{array}{l}\text { Lkhagvadorj et al. } \\
{[13]}\end{array}$ & $\begin{array}{l}\text { B. breve, } \\
\text { B. dentium, } \\
\text { B. pseudo-catenulatum }\end{array}$ & $\begin{array}{l}\text { - Survival of cells treated with 5-FU } \\
\text { and then infected with MRSA } \\
\text { increased }\end{array}$ & $\begin{array}{l}\text { The combination of } B . \text { breve and } \\
\text { galactooligosaccharides exhibited } \\
\text { activity against MRSA }\end{array}$ \\
\hline Yang et al. [14] & B. breve & $\begin{array}{l}\text { - Expression of } t c d A \text { and } t c d B \\
\text { decreased when combined with } \\
\text { antibiotics, including metronidazole, } \\
\text { clindamycin, and ceftazidime }\end{array}$ & $\begin{array}{l}\text { The antibacterial effects of } C \text {. difficile } \\
\text { were enhanced when } B \text {. breve was } \\
\text { combined with certain antibiotics }\end{array}$ \\
\hline Toscano et al. [15] & $\begin{array}{l}\text { L. rhamnosus, } \\
\text { B. longum }\end{array}$ & $\begin{array}{l}\text { - Changes in intestinal microbial } \\
\text { composition } \\
\text { - Harmful bacteria decreased }\end{array}$ & $\begin{array}{l}\text { Probiotics changed the intestinal } \\
\text { microflora by reducing harmful } \\
\text { bacteria and increasing beneficial } \\
\text { bacteria }\end{array}$ \\
\hline
\end{tabular}

5-FU, 5-fluorouracil; MRSA, multidrug-resistant S. aureus; VISA, vancomycin-resistant S. aureus; VRE, vancomycin-resistant Enterococcus. 
Table 2. Antiviral effects of Bifidobacterium spp.

\begin{tabular}{|c|c|c|c|}
\hline Reference & Strain(s) & Outcomes and results & Discussion \\
\hline $\begin{array}{l}\text { Gagnon et al. } \\
\text { [17] }\end{array}$ & $\begin{array}{l}\text { B. thermophilum, } \\
\text { B. thermacido-philum, } \\
\text { B. longum, } \\
\text { B. pseudolongum }\end{array}$ & $\begin{array}{l}\text { - Inhibition of adherence of rotavirus to } \\
\text { Caco-2 and HT- } 29 \text { cells after } \\
\text { pretreatment with } B \text {. thermophilum } \\
\text { - Number of rotavirus, duration } \\
\text { of diarrhea, and epithelial lesion } \\
\text { decreased after treatment with } \\
\text { B. thermophilum }\end{array}$ & $\begin{array}{l}\text { Bifidobacteria contributed to the } \\
\text { inhibition of rotavirus infections, and } \\
\text { ultimately resulted in reduced } \\
\text { transmission }\end{array}$ \\
\hline $\begin{array}{l}\text { Ishizuka et al. } \\
{[18]}\end{array}$ & $\begin{array}{l}\text { B. infantis, } \\
\text { B. breve }\end{array}$ & $\begin{array}{l}\text { - Controlled release of antiviral } \\
\text { substances } \\
\text { - Rotaviral infectivity of PIE cells } \\
\text { decreased with } B \text {. infantis or } B \text {. breve } \\
\text { pretreatment }\end{array}$ & $\begin{array}{l}\text { It is possible to replace antiviral drugs } \\
\text { with a bifidobacteria formula to inhibit } \\
\text { rotavirus infections in animals }\end{array}$ \\
\hline $\begin{array}{l}\text { Vlasova et al. } \\
\text { [19] }\end{array}$ & $\begin{array}{l}\text { L. rhamnosus, } \\
\text { B. animalis }\end{array}$ & $\begin{array}{l}\text { - Virus shedding titer decreased } \\
\text { - Viral diarrhea period reduced }\end{array}$ & $\begin{array}{l}\text { Diarrhea of neonatal gnotobiotic pig by } \\
\text { human rotavirus was mitigated }\end{array}$ \\
\hline $\begin{array}{l}\text { Muñoz et al. } \\
{[20]}\end{array}$ & $\begin{array}{l}\text { B. longum subsp. } \\
\text { infantis }\end{array}$ & $\begin{array}{l}\text { - Virus shedding decreased } \\
\text { - Fecal sIgA increased }\end{array}$ & $\begin{array}{l}\text { B. infantis showed an initial protective } \\
\text { effect against infection with the murine } \\
\text { rotavirus } \mathrm{McN} \text { strain }\end{array}$ \\
\hline $\begin{array}{l}\text { Holscher et al. } \\
{[21]}\end{array}$ & B. lactis & $\begin{array}{l}\text { - Fecal anti-rotaviral and anti-polioviral } \\
\text { IgA increased after vaccination }\end{array}$ & $\begin{array}{l}\text { The lack of immunity in infants not } \\
\text { breastfed or delivered by cesarean } \\
\text { sectioning was mitigated by safely } \\
\text { introducing immune-controlling } \\
\text { bacteria through a Bb12 formula }\end{array}$ \\
\hline
\end{tabular}

IgA, immunoglobulin A; PIE, porcine intestinal epitheliocytes.

fecal secretory IgA [20]. In a randomized and controlled trial, breast-fed infants had higher fecal secretory immunoglobulin A (sIgA) concentrations than formula-fed infants, and the fecal sIgA concentration increased with B. lactis consumption. Likewise, anti-rotaviral and anti-polioviral sIgA increased after B. lactis consumption in cesarean-delivered infants, suggesting that the immune system of formula-fed and cesarean-delivered infants can be improved by the intake of bifidobacteria (Table 2) [21].

\section{Antimicrobial Mechanisms}

As described above, numerous studies have confirmed the antibacterial and antiviral activities of probiotics, including those of Bifidobacterium strains. The mechanisms of these effects were investigated mostly in vitro. In a study conducted to confirm whether the viability of bifidobacteria determined their adhesion to the cell, various

Table 3. Antimicrobial mechanisms of Bifidobacterium spp.

\begin{tabular}{|c|c|c|c|}
\hline References & Strain $(s)$ & Outcomes and results & Discussion \\
\hline Wang et al. [22] & B. animalis & $\begin{array}{l}\text { - Adhesion was reduced without any } \\
\text { change in viability when treated with } \\
\text { enzymes } \\
\text { - Viability was reduced but adhesion } \\
\text { maintained when treated with lithium } \\
\text { chloride } \\
\text { - Viability was reduced to zero but } \\
\text { adhesion increased when treated with } \\
\text { sodium metaperiodate }\end{array}$ & $\begin{array}{l}\text { The adhesion of bifidobacteria was } \\
\text { determined by the substance on the outer } \\
\text { layer of the cell wall, and not bacterial cell } \\
\text { viability }\end{array}$ \\
\hline $\begin{array}{l}\text { Natividad et al. } \\
\text { [23] }\end{array}$ & B. breve & $\begin{array}{l}\text { - Expression of the REGIII- } \gamma \text { antibacterial } \\
\text { peptide increased } \\
\text { - Expression of REGIII- } \alpha \text {, a human } \\
\text { homolog of REGIII- } \gamma \text {, increased }\end{array}$ & $\begin{array}{l}\text { A correlation existed between the } \\
\text { expression of REGIII- } \gamma \text { in the colon and } \\
\text { the composition of microflora. } B \text {. breve } \\
\text { effectively induced REGIII expression }\end{array}$ \\
\hline El Kfoury et al. [24] & $\begin{array}{l}\text { B. longum, } \\
\text { B. breve }\end{array}$ & $\begin{array}{l}\text { - Protective effect against coxsackievirus } \\
\text { increased when bifidobacteria was } \\
\text { cultured with viral particles } \\
\text { - Damage to HEp-2 cells by CV-B4 E2 was } \\
\text { inhibited when CV-B4 was preincubated } \\
\text { with LpA of bifidobacteria }\end{array}$ & $\begin{array}{l}\text { The LpA-derived protein of bifidobacteria } \\
\text { prevented CV-B4 infection. This effect was } \\
\text { attributed to the interaction of the protein } \\
\text { with a viral capsid protein in CAR }\end{array}$ \\
\hline $\begin{array}{l}\text { Fernandez-Duarte } \\
\text { et al. }[25]\end{array}$ & $\begin{array}{l}\text { B. adolescentis, } \\
\text { L. casei, } \\
\text { L. fermentum, } \\
\text { B. bifidum }\end{array}$ & $\begin{array}{l}\text { - No difference in rotavirus infectivity } \\
\text { when pretreated with probiotic } \\
\text { metabolites } \\
\text { - Challenge after co-incubation of } \\
\text { metabolites with virus; infectivity } \\
\text { decreased }\end{array}$ & $\begin{array}{l}\text { Metabolites of L. casei and B. adolescentis } \\
\text { transformed the rotavirus protein, thus } \\
\text { reducing its ability to effectively attach to } \\
\text { MA104 cells }\end{array}$ \\
\hline
\end{tabular}

CAR, coxsackievirus and adenovirus receptor; LpAs, lipoprotein aggregates. 


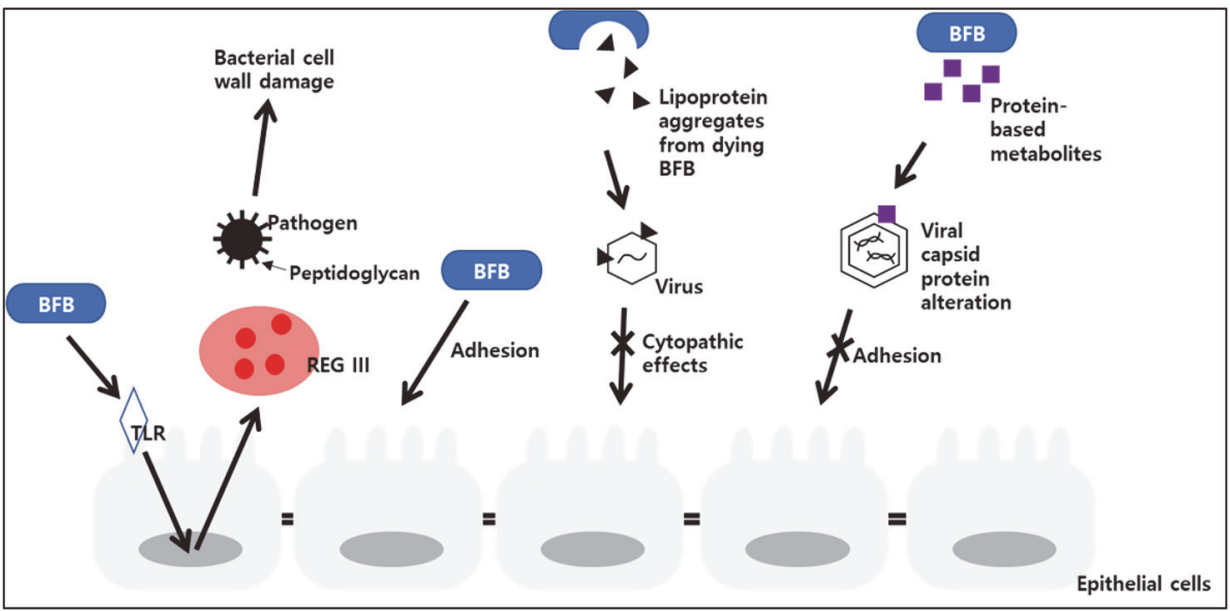

Fig. 1. Antimicrobial mechanisms of bifidobacteria.

enzymes and chemical compounds were treated with B. animalis. The results showed that a substance on the outer layer of the cell wall, and not the viability of the cell, affected the adherence ability of bifidobacteria. It was observed that, while treatment with digestive enzymes reduced the adhesion ability of bifidobacteria, it did not significantly affect cell viability. Furthermore, sodium metaperiodate treatment completely killed the bacteria, but their adhesion ability increased [22]. With regards to gene expression, the expression of REGIII- $\gamma$ (a murine antibacterial peptide that is expressed more effectively when the microflora is more diverse) was induced after the inoculation of $B$. breve. Similarly, the expression of REGIII- $\alpha$, a human homolog of REGIII- $\gamma$, was induced when live and heat-inactivated $B$. breve were inoculated into Caco-2 cells [23]. This reflected strengthening of the mucous membrane and the protective effects of $B$. breve against infection and inflammation.

A study investigating the mechanism of the antiviral effect of bifidobacteria showed that, when B. longum was cultured for $72 \mathrm{~h}$, the number of bacteria decreased but they were still effective in protecting cells against coxsackievirus-induced cytopathogenicity. This effect was attributed to an increase in the concentration of a compound on the cell walls of the dying bifidobacteria. Further investigation revealed that the compound was lipoprotein A, which combined with a viral capsid protein, the coxsackievirus and adenovirus receptor. Interestingly, the protective effect was observed when bifidobacteria were pre-incubated with the virus, but not with HEp-2 cells [24]. Similar results were obtained in a study in which the anti-rotaviral activity of bifidobacteria was evaluated in MA104 cells. When probiotic metabolites were pre-incubated with rotavirus, infectivity of the cells was reduced. In this case, the single metabolite that significantly reduced viral infections was a protein-based metabolite extracted from B. adolescentis (Table 3, Fig. 1) [25].

\section{Immunomodulatory Effects}

\section{Pro-inflammatory Effects}

In a trial involving nondiabetic subjects, the serum levels of pro-inflammatory cytokines (i.e., interleukin (IL)12 , interferon- $\gamma($ IFN- $\gamma)$, and immunoglobulin 1$)$ increased significantly in the test group that was fed dairy yogurt containing $L$. paracase $i, B$. lactis and heat-killed L. plantarum. In addition, there was an increase in the activity of natural killer cells. The results suggested that eating dairy products can help enhance immune responses [26]. In another study, IL-1 $\beta$, tumor necrosis factor- $\alpha$ (TNF- $\alpha$ ), and nitrous oxide were released additively when Bifidobacterium strains were treated with lipopolysaccharide (LPS). Furthermore, the presentation of antigens by dendritic cells increased, and cells treated with the supernatant of bifidobacteria were larger and rougher than those exposed to the medium or LPS alone [27]. In a study using a colonic explant, transcription of IL- $1 \alpha$ and IL- $1 \beta$ increased when B. bifidum was added to the medium. In that study, expression of the polymeric immunoglobulin receptor, responsible for the export of dimeric/polymeric IgA across the intestinal epithelium and contributing to increased sIgA secretion, increased in a concentration-dependent manner [28]. This implied an increase in toll-like receptor signaling (Table 4).

\section{Anti-Inflammatory Effects}

The concentration of TNF- $\alpha$ increased in the colons of mice with dextran sodium sulfate-induced colitis. However, the administration of $B$. lactis reversed this effect, which led to a reduction in intestinal epithelial cell apoptosis. In addition, the administration of B. lactis improved pathological properties, such as shortening of colon length, induced by dextran sodium sulfate [29].

In another study, when HT-29 cells were pre-incubated with conditioned media (CM) of intestinal Bifidobacterium strains (isolated from healthy infants), the production of IL-8 in response to TNF- $\alpha$ and E. coli 055:B5 LPS was significantly inhibited. In particular, CM of all B. bifidum strains (except Bif2) used in this study significantly inhibited IL- 8 production by LPS. The transcription of transforming growth factor- $\beta 1$ (TGF- $\beta 1$; an anti-inflammatory cytokine) and expression of p21CIP (a cyclin-dependent kinase suppressor) increased when 
Table 4. Pro-inflammatory effects of Bifidobacterium spp.

\begin{tabular}{|c|c|c|c|}
\hline References & Strain(s) & Outcomes and results & Discussion \\
\hline $\begin{array}{l}\text { Lee et al. } \\
{[26]}\end{array}$ & $\begin{array}{l}\text { L. paracasei ssp. } \\
\text { paracasei, } \\
\text { B. animalis spp. lactis, } \\
\text { L. plantarum }\end{array}$ & $\begin{array}{l}\text { - TNF- } \alpha \text {, IFN- } \gamma \text {, IL-12, and IgG1 } \\
\text { increased }\end{array}$ & $\begin{array}{l}\text { L. paracasei, B. lactis, and heated } \\
\text { L. plantarum can play key roles in } \\
\text { enhancing the immunity of } \\
\text { immunosuppressed patients }\end{array}$ \\
\hline $\begin{array}{l}\text { Han et al. } \\
{[27]}\end{array}$ & $\begin{array}{l}\text { B. pseudocatenulatum, } \\
\text { B. longum, } \\
\text { B. breve }\end{array}$ & $\begin{array}{l}\text { - External antigen ovalbumin increased } \\
\text { - NO release increased } \\
\text { - IL-1 } \beta \text { and TNF- } \alpha \text { increased } \\
\text { - Macrophages were larger and rougher }\end{array}$ & $\begin{array}{l}\text { Bifidobacteria activated macrophages and } \\
\text { enhanced APC cell functions through } \\
\text { MHC class molecules, and increased the } \\
\text { secretion of macrophage intermediates }\end{array}$ \\
\hline $\begin{array}{l}\text { Nakamura } \\
\text { et al. }[28]\end{array}$ & B. bifidum & $\begin{array}{l}\text { - pIgR mRNA increased } \\
\text { - Expression of IL- } 1 \alpha \text { and IL- } 1 \beta \text { increased }\end{array}$ & $\begin{array}{l}\text { Expression of intestinal pIgR increased } \\
\text { site-specifically. This can be explained by } \\
\text { the action of epithelial cells through TLRs }\end{array}$ \\
\hline
\end{tabular}

APC, antigen presenting cell; IL-1 $\beta$, interleukin 1 beta; MHC, major histocompatibility complex; NO, nitric oxide; pIgR, polymeric immunoglobulin receptor; TLRs, toll-like receptors; TNF- $\alpha$, tumor necrosis factor- $\alpha$.

the mice were treated with CM and LPS or TNF- $\alpha$. Although the active substance was not defined, it was not a protein or nucleic acid, because the anti-inflammatory activity was maintained when the CM was treated with proteinase K or a DNase/Rnase mix (after ultrafiltration using a $9 \mathrm{kDa}$ cut-off filter) [30]. Further, in a study using RAW 264.7 macrophages, the concentrations of LPS and TNF- $\alpha$ decreased in all the tested Bifidobacterium strains (i.e., B. bifidum, B. longum, and B. longum subsp. Infantis). In addition, the concentration of another proinflammatory cytokine, IL-1 $\beta$, decreased in B. bifidum (Table 5) [31].

\section{Immunomodulatory Effects}

In a study using peripheral blood mononuclear cells isolated from the venous blood of ulcerative colitis (UC) patients, two ultraviolet irradiation-killed probiotic strains, L. acidophilus and B. lactis, increased the levels of proinflammatory (IFN- $\gamma$ and TNF- $\alpha$ ) and anti-inflammatory (IL-10 and TGF- $\beta$ ) cytokines when compared to those in the control group (peripheral blood mononuclear cells incubated with RPMI-1640 medium). In particular, the levels of IL-10 and TGF- $\beta$ were relatively higher, while the levels of IFN- $\gamma$ and TNF- $\alpha$ appeared to be lower in the B. lactis group. The levels of IFN- $\gamma$ and TNF- $\alpha$ were lower at $72 \mathrm{~h}$ compared to those at $48 \mathrm{~h}$, which could be due to the increase in IL-10 and TGF- $\beta$ levels. Thus, it was concluded that $B$. lactis can be administered as an alternative treatment in UC patients suffering from inflammatory responses because it has a more significant effect on the activation of T-regulatory cells and less effect on the activation of T-helper cells, when compared to L. acidophilus [32].

In another in vitro study using keratinocytes and fibroblasts incubated with inactivated $S$. aureus, the concentration of IL-18 increased after treatment with inactivated B. breve and B. pseudolongum. Furthermore, the levels of IL- 8 decreased in all inactivated bacteria and live B. longum and B. pseudolongum, and the decrease was greater in the inactivated bacteria. In the case of IL-6, an anti-inflammatory cytokine, all tested inactivated and live bifidobacteria reduced its levels, with the exception of live B. pseudolongum $119^{1 \mathrm{~A}}$ [33].

In an in vivo experiment using mice infected with Klebsiella pneumoniae, the number of inflammatory cells in the lungs was reduced, and the concentration of pro-inflammatory cytokines (TNF- $\alpha$ and IL-6) in bronchoalveolar fluid (which increased after infection with $K$. pneumoniae) was also significantly reduced, when live or inactivated $B$. longum $5^{1 \mathrm{~A}}$ was administered. Moreover, when live $B$. longum $5^{1 \mathrm{~A}}$ was administered, production of the anti-inflammatory cytokine, IL-10, was induced in the liver at a significantly higher level

Table 5. Anti-inflammatory effects of Bifidobacterium spp.

\begin{tabular}{|c|c|c|c|}
\hline References & Strain $(\mathrm{s})$ & Outcomes and results & Discussion \\
\hline $\begin{array}{l}\text { Chae et al. } \\
{[29]}\end{array}$ & B. animalis subsp. Lactis & $\begin{array}{l}\text { - Shortening of colon length reduced } \\
\text { - Pathological properties of colon by DSS } \\
\text { treatment decreased } \\
\text { - DSS-induced apoptosis of intestinal } \\
\text { epithelial cell decreased } \\
\text { - Increased TNF- } \alpha \text { of DSS-treated mouse } \\
\text { reduced }\end{array}$ & $\begin{array}{l}\text { BB12 lowered the sensitivity to colitis, } \\
\text { induced by DSS, and reduced the } \\
\text { apoptosis of intestinal epithelial cells. } \\
\text { This was attributed to the reduction in } \\
\text { TNF- } \alpha\end{array}$ \\
\hline $\begin{array}{l}\text { Khokhlova } \\
\text { et al. [30] }\end{array}$ & $\begin{array}{l}\text { B. bifidum, } \\
\text { B. longum, } \\
\text { B. breve, } \\
\text { B. adolescentis }\end{array}$ & $\begin{array}{l}\text { - Inhibited IL- } 8 \text { secretion of LPS-treated } \\
\text { HT- } 29 \text { cells (conditioned medium of all } \\
\text { tested strains) }\end{array}$ & $\begin{array}{l}\text { Bifidobacteria controlled the signaling } \\
\text { pathway in epithelial cells and was } \\
\text { species-specific }\end{array}$ \\
\hline $\begin{array}{l}\text { Rodes et al. } \\
{[31]}\end{array}$ & $\begin{array}{l}\text { L. rhamnosus, } \\
\text { B. bifidum, } \\
\text { B. longum, } \\
\text { B. longum subsp. Infantis }\end{array}$ & $\begin{array}{l}\text { - Concentration of LPS decreased } \\
\text {-TNF- } \alpha \text { and IL- } 1 \beta \text { decreased in intestinal } \\
\text { LPS }\end{array}$ & $\begin{array}{l}\text { Probiotics lowered the intestinal LPS } \\
\text { concentration and reduced the secretion } \\
\text { of pro-inflammatory cytokines in } \\
\text { macrophages }\end{array}$ \\
\hline
\end{tabular}

DSS, dextran sodium sulfate; IL-8, interleukin 8; IL-1 $\beta$, interleukin 1 beta; LPS, lipopolysaccharide; TNF- $\alpha$, tumor necrosis factor- $\alpha$. 
Table 6. Immunomodulatory mechanism of Bifidobacterium spp.

\begin{tabular}{|c|c|c|c|}
\hline References & Strain $(\mathrm{s})$ & Outcomes and results & Discussion \\
\hline $\begin{array}{l}\text { Sheikhi et al. } \\
{[32]}\end{array}$ & $\begin{array}{l}\text { L. acidophilus, } \\
\text { B. lactis }\end{array}$ & $\begin{array}{l}\text { - IL-10, TGF- } \beta \text {, IFN- } \gamma \text {, and TNF- } \alpha \text { increased } \\
\text { compared to control in both probiotic } \\
\text { groups } \\
\text { - IL- } 10 \text {, TGF- } \beta \text { were relatively higher in } \\
\text { B. lactis group } \\
\text { - IFN- } \gamma \text {, TNF- } \alpha \text { appeared to be relatively } \\
\text { lower in the } B \text {. lactis group }\end{array}$ & $\begin{array}{l}\text { B. lactis activated not only Th, but also Treg } \\
\text { cells. It can be used as a treatment alternative } \\
\text { for UC patients }\end{array}$ \\
\hline $\begin{array}{l}\text { Silva et al. } \\
\text { [33] }\end{array}$ & $\begin{array}{l}\text { B. longum, } \\
\text { B. breve, } \\
\text { B. pseudolongum, } \\
\text { B. bifidum }\end{array}$ & $\begin{array}{l}\text { - Bacterial growth of all strains was inhibited } \\
\text { - Decrease in IL-8 was greater with live } \\
\text { B. longum } \\
\text { - IL-6 decreased in all live bacteria }\end{array}$ & $\begin{array}{l}\text { B. longum showed antibacterial activity, and } \\
\text { B. bifidum and B. bifidum were effective in } \\
\text { producing cytokines and extracellular } \\
\text { matrix }\end{array}$ \\
\hline $\begin{array}{l}\text { Vieira et al. } \\
\text { [34] }\end{array}$ & B. longum & $\begin{array}{l}\text { - TNF- } a \text { and IL-6, which were increased } \\
\text { after K. pneumoniae infection in } \\
\text { bronchoalveolar fluid, decreased } \\
\text { - Increased IL-10 with live B. longum } \\
\text { - Increased ROS production with greater } \\
\text { effect of live bacteria }\end{array}$ & $\begin{array}{l}\text { Live } B \text {. longum probiotics can activate the } \\
\text { TLR signal pathway to generate ROS, } \\
\text { regulate the inflammatory response, and } \\
\text { help the lungs quickly restore constancy }\end{array}$ \\
\hline
\end{tabular}

IL, interleukin; ROS, reactive oxygen species; TGF, transforming growth factor; Th, T-helper cells; Treg, T-regulatory cells; TLR, toll-like receptor; TNF- $\alpha$, tumor necrosis factor- $\alpha$; UC, ulcerative colitis.

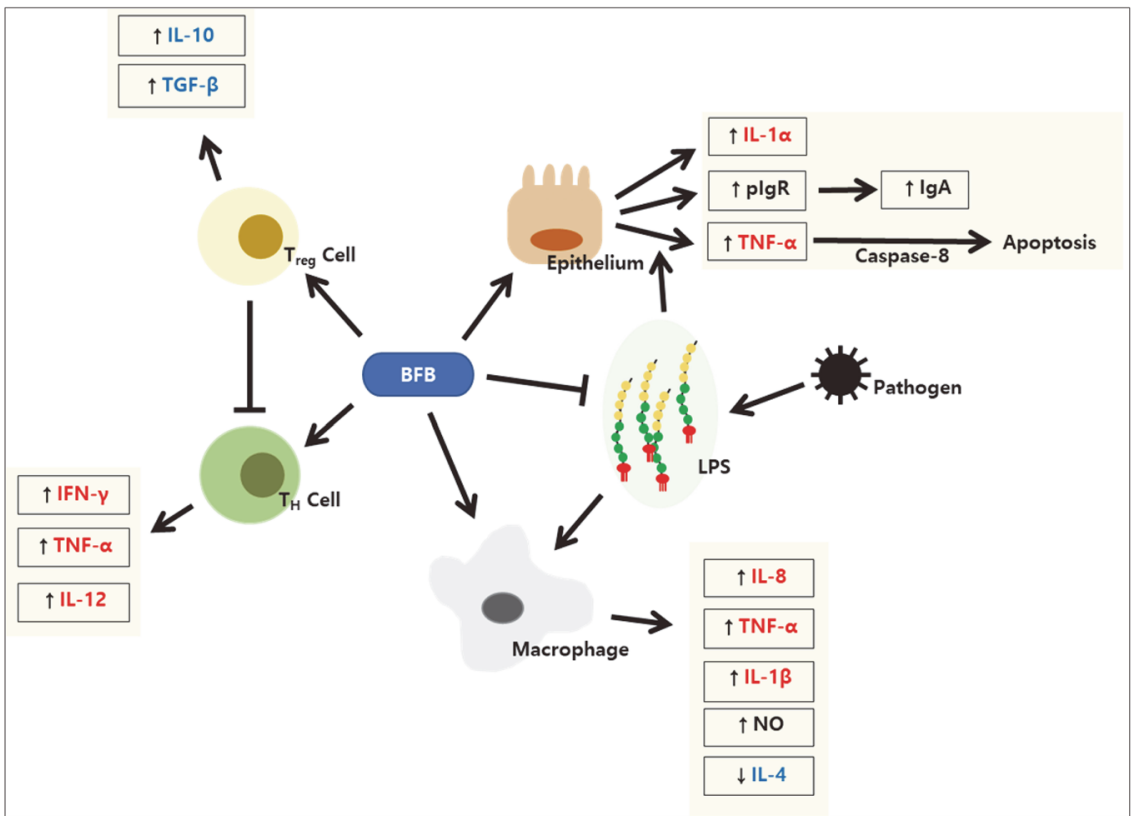

Fig. 2. Immunomodulatory mechanisms of bifidobacteria.

compared to that in the control group. In contrast, similar results were not observed with inactivated B. longum, suggesting that substances produced by live bacteria induce IL-10 production; this substance was later revealed as acetate. On the other hand, the concentration of a chemokine (CXCL1) increased when live B. longum $5^{1 \mathrm{~A}}$ was administered to germ-free mice, and both live and inactivated $B$. longum $5^{1 \mathrm{~A}}$ induced reactive oxygen species production in alveolar macrophages, resulting in the elimination of $K$. pneumoniae (Table 6, Fig. 2) [34].

\section{Conclusions}

Bifidobacterium strains show antibacterial effects against various pathogens, and some inhibit multidrugresistant pathogens. In addition, some strains exhibit antiviral effects by inhibiting adherence of the virus to the cells and lowering the viral titer, both in vitro and in vivo. Substances, such as lipoprotein A, found on the outer layer of bifidobacterial cell walls, inhibit pathogens and, in some cases, bifidobacteria induce the expression of antimicrobial substances, such as REGIII, in epithelial cells. Bifidobacteria show both pro- and anti-inflammatory effects. Studies have demonstrated that the expression of inflammatory cytokines, including TNF- $\alpha$ and IL-1, is increased and the activity of natural killer cells is promoted by bifidobacteria, suggesting their potential therapeutic effect in immunosuppressed patients. Other findings show that bifidobacteria inhibit rotaviral adherence leading to less damage of intestinal epithelial tissue. Furthermore, there is a lower virus shedding titer and shorter diarrhea period, along with an increase in sIgA. Additionally, some strains show anti-inflammatory 
effects by lowering the levels of TNF- $\alpha$, IL- 8 , and IL- $1 \beta$. These effects are particularly helpful in the treatment of inflammatory diseases, including colitis or LPS-induced conditions. In the cases of UC or S. aureus and $K$. pneumoniae infections, bifidobacteria modulate the immune system by inducing or suppressing both pro- and anti-inflammatory cytokines. Overall, these results suggest the effectiveness of Bifidobacterium strains as potential therapies for infectious or inflammatory diseases. In order for Bifidobcterium strains to be applied for pharmaceutical uses, further in vivo studies should be conducted to ensure effectivity and safety of bifidobacterial products in human bodies.

\section{Acknowledgments}

This research was supported by the Basic Science Research Program through the NRF funded by the Ministry of Education (2017R1D1A1B03031273).

\section{Conflict of Interest}

The authors have no financial conflicts of interest to declare.

\section{References}

1. Cortesia C, Vilchèze C, Bernut A, Contreras W, Gómez K, de Waard J, et al. 2014. Acetic Acid, the active component of vinegar, is an effective tuberculocidal disinfectant. mBio 5: e00013-14.

2. Fraise AP, Wilkinson MA, Bradley CR, Oppenheim B, Moiemen N. 2013. The antibacterial activity and stability of acetic acid. J. Hosp. Infect. 84: 329-331.

3. Turroni F, Peano C, Pass DA, Foroni E, Severgnini M, Claesson MJ, et al. 2012. Diversity of bifidobacteria within the infant gut microbiota. PLoS One 7: e36957.

4. Mitsou EK, Kirtzalidou E, Oikonomou I, Liosis G, Kyriacou A. 2008. Fecal microflora of Greek healthy neonates. Anaerobe 14: $94-$ 101.

5. Balakrishnan RS. 2007. The normal bacterial flora of the human intestine and its regulation. J. Clin. Gastroenterol. 41: S2-S6

6. DuPont AW, DuPont HL. 2011. The intestinal microbiota and chronic disorders of the gut. Nat. Rev. Gastroenterol. Hepatol. 8: $523-$ 531.

7. Inturri R, Stivala A, Furneri PM, Blandino G. 2016. Growth and adhesion to HT-29 cells inhibition of Gram-negatives by Bifidobacterium longum BB536 e Lactobacillus rhamnosus HN001 alone and in combination. Eur. Rev. Med. Pharmacol. Sci. 20: 4943-4949.

8. Lee DK, Park SY, An HM, Kim JR, Kim MJ, Lee SW, et al. 2011. Antimicrobial activity of Bifidobacterium spp. isolated from healthy adult Koreans against cariogenic microflora. Arch. Oral Biol. 56: 1047-1054.

9. Lee DK, Kim MJ, Ham JW, An HM, Cha MK, Lee SW, et al. 2012. In vitro evaluation of antibacterial activities and anti-inflammatory effects of Bifidobacterium spp. addressing acne vulgaris. Arch. Pharm. Res. 35: 1065-1071.

10. Muñoz-Quezada S, Chenoll E, Vieites JM, Genovés S, Maldonado J, Bermúdez-Brito M, et al. 2013. Isolation, identification and characterisation of three novel probiotic strains (Lactobacillus paracasei CNCM I-4034, Bifidobacterium breve CNCM I-4035 and Lactobacillus rhamnosus CNCM I-4036) from the faeces of exclusively breast-fed infants. Br. J. Nutr. 109: S51-S62

11. Abdelhamid AG, Esaam A, Hazaa MM. 2018. Cell free preparations of probiotics exerted antibacterial and antibiofilm activities against multidrug resistant E. coli. Saudi Pharm. J. 26: 603-607.

12. Yoon JH, Kim YA, Song MS, Kang BY, Ha NJ. 2006. Lactic acid bacteria isolated from healthy Korean having antimicrobial activity against VISA and VRE. Yakhak Hoeji 50: 78-83.

13. Lkhagvadorj E, Nagata S, Wada M, Bian L, Wang C, Chiba Y, et al. 2010. Anti-infectious activity of synbiotics in a novel mouse model of methicillin-resistant Staphylococcus aureus infection. Microbiol. Immunol. 54: 265-275.

14. Yang J, Yang H. 2018. Effect of Bifidobacterium breve in combination with different antibiotics on Clostridium difficile. Front. Microbiol. 9: 2953.

15. Toscano M, De Grandi R, Stronati L, De Vecchi E, Drago L. 2017. Effect of Lactobacillus rhamnosus HN001 and Bifidobacterium longum BB536 on the healthy gut microbiota composition at phyla and species level: a preliminary study. World J. Gastroenterol. 23: 2696-2704.

16. Parashar UD, Hummelman EG, Bresee JS, Miller MA, Glass RI. 2003. Global illness and deaths caused by rotavirus disease in children. Emerg. Infect. Dis. 9: 565-572.

17. Gagnon M, Vimont A, Darveau A, Fliss I, Jean J. 2016. Study of the ability of bifidobacteria of human origin to prevent and treat rotavirus infection using colonic cell and mouse models. PLoS One 11: e0164512.

18. Ishizuka T, Kanmani P, Kobayashi H, Miyazaki A, Soma J, Suda Y, et al. 2016. Immunobiotic bifidobacteria strains modulate rotavirus immune response in porcine intestinal epitheliocytes via pattern recognition receptor signaling. PLoS One 11: e0152416.

19. Vlasova AN, Chattha KS, Kandasamy S, Liu Z, Esseili M, Shao L, et al. 2013. Lactobacilli and bifidobacteria promote immune homeostasis by modulating innate immune responses to human rotavirus in neonatal gnotobiotic pigs. PLoS One 8: e76962.

20. Muñoz JA, Chenoll E, Casinos B, Bataller E, Ramón D, Genovés S, et al. 2011. Novel probiotic Bifidobacterium longum subsp. infantis CECT 7210 strain active against rotavirus infections. Appl. Environ. Microbiol. 77: 8775-8783.

21. Holscher HD, Czerkies LA, Cekola P, Litov R, Benbow M, Santema S, et al. 2012. Bifidobacterium lactis Bb12 enhances intestinal antibody response in formula-fed infants: a randomized, double-Blind, controlled trial. J. Parenter. Enteral. Nutr. 36: 106S-117S

22. Wang LQ, Zhao F, Liu F, Meng XC. 2013. Live/dead state is not the factor influencing adhesion ability of Bifidobacterium animalis KLDS2.0603. J. Microbiol. 51: 584-589.

23. Natividad JM, Hayes CL, Motta JP, Jury J, Galipeau HJ, Philip V, et al. 2013. Differential induction of antimicrobial REGIII by the intestinal microbiota and Bifidobacterium breve NCC2950. Appl. Environ. Microbiol. 79: 7745-7754.

24. El Kfoury KA, Romond MB, Scuotto A, Alidjinou EK, Dabboussi F, Hamze M, et al. 2017. Bifidobacteria-derived lipoproteins inhibit infection with coxsackievirus B4 in vitro. Int. J. Antimicrob. Agents 50: 177-185.

25. Fernandez-Duarte KP, Olaya-Galán NN, Salas-Cárdenas SP, Lopez-Rozo J, Gutierrez-Fernandez MF. 2018. Bifidobacterium adolescentis (DSM 20083) and Lactobacillus casei (Lafti L26-DSL): probiotics able to block the in vitro adherence of rotavirus in MA104 cells. Probiotics Antimicrob. Proteins 10: 56-63.

26. Lee A, Lee YJ, Yoo HJ, Kim M, Chang Y, Lee DS, et al. 2017. Consumption of dairy yogurt containing Lactobacillus paracasei ssp. paracasei, Bifidobacterium animalis ssp. lactis and heat-treated Lactobacillus plantarum improves immune function including natural killer cell activity. Nutrients 9: 558 .

27. Han S, Cho K, Lee CK, Song Y, Park SH, Ha NJ, et al. 2005. Enhancement of antigen presentation capability of dendritic cells and activation of macrophages by the components of Bifidobacterium pseudocatenulatum SPM 1204. J. Appl. Pharmacol. 13: 174-180. 
28. Nakamura Y, Terahara M, Iwamoto T, Yamada K, Asano M, Kakuta S, et al. 2012. Upregulation of polymeric immunoglobulin receptor expression by the heat-inactivated potential probiotic Bifidobacterium bifidum OLB6378 in a mouse intestinal explant model. Scand. J. Immunol. 75: 176-183.

29. Chae JM, Heo W, Cho HT, Lee DH, Kim JH, Rhee MS, et al. 2018. Effects of orally-administered Bifidobacterium animalis subsp. lactis strain BB12 on dextran sodium sulfate-induced colitis in mice. J. Microbiol. Biotechnol. 28: 1800-1805.

30. Khokhlova EV, Smeianov VV, Efimov BA, Kafarskaia LI, Pavlova SI, Shkoporov AN. 2012. Anti-inflammatory properties of intestinal Bifidobacterium strains isolated from healthy infants. Microbiol. Immunol. 56: 27-39.

31. Rodes L, Khan A, Paul A, Coussa-Charley M, Marinescu D, Tomaro-Duchesneau C, et al. 2013. Effect of probiotics Lactobacillus and Bifidobacterium on gut-derived lipopolysaccharides and inflammatory cytokines: an in vitro study using a human colonic microbiota model. J. Microbiol. Biotechnol. 23: 518-526.

32. Sheikhi A, Shakerian M, Giti H, Baghaeifar M, Jafarzadeh A, Ghaed V, et al. 2016. Probiotic yogurt culture Bifidobacterium animalis subsp. lactis BB-12 and Lactobacillus acidophilus LA-5 modulate the cytokine secretion by peripheral blood mononuclear cells from patients with ulcerative colitis. Drug Res. (Stuttg) 66: 300-305.

33. Silva AKS, Silva TRN, Nicoli JR, Vasquez-Pinto LMC, Martins FS. 2018. In vitro evaluation of antagonism, modulation of cytokines and extracellular matrix proteins by Bifidobacterium strains. Lett. Appl. Microbiol. 67: 497-505.

34. Vieira AT, Rocha VM, Tavares L, Garcia CC, Teixeira MM, Oliveira SC, et al. 2016. Control of Klebsiella pneumoniae pulmonary infection and immunomodulation by oral treatment with the commensal probiotic Bifidobacterium longum $5^{1 \mathrm{~A}}$. Microbes Infect. 18: $180-189$. 